\title{
Effect of Ionophores on the ATP-pool and Glycerol Content in Cells of the Halotolerant Green Alga Dunaliella tertiolecta
}

\author{
By DIRK BELMANS* AND ANDRÉ VAN LAERE \\ Department of Plant Physiology and Biochemistry, Laboratory for Developmental Biology, \\ Katholieke Universiteit Leuven, Kardinaal Mercierlaan 92, B-3030 Heverlee, Belgium
}

(Received 12 February 1988; revised 18 April 1988)

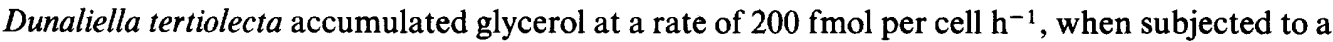
hyperosmotic shock of $0.930 \mathrm{osmol}^{-1}$ with $\mathrm{NaCl}$ or mannitol. In alkaline media, a slight inhibition of the osmotic response, to $130 \mathrm{fmol} \mathrm{per} \mathrm{cell} \mathrm{h}^{-1}$ at $\mathrm{pH}$ 9, was found. Acetate or ammonium ions markedly decreased osmoinduced glycerol synthesis under $\mathrm{pH}$ conditions where the uncharged form of these agents was present at concentrations exceeding $2 \mathrm{mM}$. The proton translocators dinitrophenol (DNP) $(0 \cdot 3-1 \mathrm{mM})$ and carbonyl cyanide $m$-chlorophenylhydrazone (CCCP) $(0.01,0.03$ and $0.05 \mathrm{mM})$ disturbed the metabolic response at all $\mathrm{pH}$ values tested. Also, DNP disturbed glycerol retention in low $\mathrm{pH}$ media, whereas CCCP did not affect the glycerol level under iso-osmotic conditions. The osmoinduced glycerol synthesis was blocked almost completely in the presence of monovalent cation ionophores such as nigericin $(0.01 \mathrm{mM})$ and monensin $\left(10 \mu \mathrm{g} \mathrm{ml}^{-1}\right)$ but not by the $\mathrm{K}^{+}$ionophore valinomycin $(0.01 \mathrm{mM})$. With all the ionophores investigated, a correlation was found between decreasing glycerol and ATP contents, indicating that glycerol synthesis requires ATP. The results are discussed in relation to the regulation of glycerol metabolism under different osmotic conditions.
\end{abstract}

\section{INTRODUCTION}

Species of the unicellular algal genus Dunaliella possess the unique capability to grow in the presence of a broad range of salt concentrations $(0 \cdot 1-5.5 \mathrm{M}-\mathrm{NaCl})$. These wall-less, green flagellates respond to changes in the extracellular water potential, by synthesis or elimination of the compatible solute glycerol, after a hypertonic and hypotonic shock, respectively (Ben-Amotz \& Avron, 1973). The osmotic response occurs in light and in darkness and is not dependent on de novo protein synthesis (Borowitzka et al., 1977).

Assay of the enzymes that are involved in glycerol metabolism points towards a 'glycerol cycle' operating in Dunaliella cells (Wegmann, 1979). Glycerol synthesis is performed by a reversible step from dihydroxyacetone phosphate to glycerol 3-phosphate catalysed by glycerol3-phosphate dehydrogenase (Haus \& Wegmann, 1984a,b), followed by an irreversible dephosphorylation by glycerol-3-phosphatase (Sussman \& Avron, 1981). Conversion of glycerol back to dihydroxyacetone phosphate proceeds via a reversible oxidation step to dihydroxyacetone by the NADP ${ }^{+}$-dependent glycerol dehydrogenase (Ben-Amotz \& Avron, 1974) and an irreversible phosphorylation step catalysed by dihydroxyacetone kinase (Lerner et al., 1980). Clearly, dihydroxyacetone phosphate, originating from photosynthesis or starch breakdown, is the key intermediate of the cyclic glycerol metabolism in Dunaliella. Since metabolism of dihydroxyacetone phosphate in the glycerol cycle would result in a futile cycle, wasting one molecule of ATP, the glycerol cycle has to be highly controlled in order to prevent excessive waste of cellular energy (Brown et al., 1982). Gimmler et al. (1981) have suggested that the phosphorylation potential plays a dominant role in the control of glycerol metabolism in

Abbreviation: CCCP, carbonyl cyanide $m$-chlorophenylhydrazone. 
Dunaliella cells. Two observations argue for this hypothesis: (1) one of the first metabolic events following an hyperosmotic shock is a sharp, but transient, decrease of the cellular ATP content, depending on the strength of the osmotic shock (Ehrenfeld \& Cousin, 1984; Belmans \& Van Laere, 1987); (2) ATP is an inhibitor of glycerol-3-phosphate dehydrogenase at physiological concentrations (Marengo et al., 1985; Haus \& Wegmann, 1984b). The intracellular concentration of ions (e.g. $\mathrm{H}^{+}, \mathrm{Na}^{+}, \mathrm{K}^{+}, \mathrm{Ca}^{2+}$ ) might also be involved in the regulation of glycerol metabolism under different osmotic conditions (Wegmann, 1979). Generally, cellular proton concentration can play a dominant role in the control of cell metabolism via its effect on enzyme system (Smith \& Raven, 1979; Busa \& Nuticelli, 1984). For several Dunaliella species, the cellular $\mathrm{Na}^{+}$content temporarily increases immediately after an hypertonic shock (Ehrenfeld \& Cousin, 1984; Ginzburg, 1981). Moreover, during the first hour after such a cell transfer a considerable $\mathrm{K}^{+}$uptake has been found in Dunaliella tertiolecta (Ehrenfeld \& Cousin, 1984). These and other observations (Katz et al., 1986) suggest that $\mathrm{Na}^{+}$and $\mathrm{K}^{+}$are important in the initial adaptation phases after an osmotic shock. The intracellular concentration of ions can be modified artificially by incubating the cells in the presence of ionophores. Ehrenfeld \& Cousin (1982) showed that the antibiotics nystatin $\left(20 \mu \mathrm{g} \mathrm{ml}^{-1}\right)$ and monensin $\left(5-60 \mu \mathrm{g} \mathrm{ml}^{-1}\right)$ both induce an increase of the intracellular $\mathrm{Na}^{+}$content of $D$. tertiolecta. Pick et al. (1986) have investigated the influence of $0.05 \mathrm{~mm}$-carbonylcyanide $p$-trifluoromethoxyphenyl-hydrazone (FCCP), 0.001 mM-valinomycin and 0.001 mM-nigericin on the ion content in Dunaliella salina. The specific $\mathrm{K}^{+}$-ionophore valinomycin hardly affects the intracellular $\mathrm{K}^{+}$and $\mathrm{Na}^{+}$content, whereas nigericin induces a significant decrease of intracellular $\mathrm{K}^{+}$and an increase of intracellular $\mathrm{Na}^{+}$.

We investigated the effect of various ionophores on cellular ATP and glycerol content, under different osmotic conditions, in order to elucidate the role of ions and ATP in the regulation of glycerol metabolism in $D$. tertiolecta. Incubation experiments with acetic acid and ammonium salts were also done to find out if intracellular $\mathrm{pH}$ is involved in the control of glycerol metabolism in this organism.

\section{METHODS}

Culture of the algae. Dunaliella tertiolecta (strain 19/6, kindly supplied by Professor K. Wegmann, University of Tübingen, $\mathrm{FRG}$ ) was grown with either 0.1 or $0.5 \mathrm{M}-\mathrm{NaCl}$ in a medium containing: $40 \mathrm{mM}-\mathrm{MgSO}_{4} ; 10 \mathrm{mM}-\mathrm{CaCl}_{2}$; $10 \mathrm{mM}-\mathrm{KNO}_{3} ; 0.15 \mathrm{mM}-\mathrm{KH}_{2} \mathrm{PO}_{4} ; 12.5 \mu \mathrm{M}-\mathrm{Na}_{2}$ EDTA; $14.7 \mu \mathrm{M}-\mathrm{FeCl}_{3} ; 184 \mu \mathrm{M}-\mathrm{H}_{3} \mathrm{BO}_{3} ; 7 \mu \mathrm{M}-\mathrm{MnCl}_{2} ; 8 \mu \mathrm{M}-$ $\mathrm{ZnCl}_{2} ; 0.206 \mu \mathrm{M}-\mathrm{Co}\left(\mathrm{NO}_{3}\right)_{2} ; 0.0002 \mu \mathrm{M}-\mathrm{CuSO}_{4}$. The $\mathrm{pH}$ of the sterilized medium was approximately 6.0. The cells were cultured at $20^{\circ} \mathrm{C}$ in continuous illumination provided by white fluorescent lamps at $22 \mathrm{~W} \mathrm{~m}^{-2}$. A stream of $2 \% \mathrm{CO}_{2}$ in air was continuously bubbled through the culture. The $D$. tertiolecta cells were adapted for several months at a given salinity before experimental use.

Incubation of the cells. D. tertiolecta cells in the late exponential phase $\left(3 \times 10^{6}\right.$ cells $\left.\mathrm{ml}^{-1}\right)$ were collected by centrifugation at room temperature and $2000 \mathrm{~g}$ for $2 \mathrm{~min}$ and washed twice with fresh culture medium before the experiments. The incubation media consisted of culture medium buffered with $25 \mathrm{mM}$-glycylglycine (pH 4 and 5), $25 \mathrm{~mm}-\mathrm{MES}$ ( $\mathrm{pH}$ 6) or 25 -mM-Tris ( $\mathrm{pH} \mathrm{7,8}$ and 9). $\mathrm{NaCl}$ (or $\mathrm{KCl}$ in the experiments with valinomycin and nigericin) and other additives were added to the media as indicated.

The experiments were started by resuspending the cells in $200 \mathrm{ml}$ of the appropriate medium to a cell density of $3 \times 10^{6}$ cells $\mathrm{ml}^{-1}$. During incubation at room temperature, the cells were gently shaken and continuously illuminated at $66 \mathrm{~W} \mathrm{~m}^{-2}$.

Determination of cell number. After adding formol up to a final concentration of $1 \%(w / v)$ to immobilize the algae, they were counted under the light microscope on a Burker slide. The volume of the smallest count chamber was $4 \mathrm{nl}$.

Extraction of glycerol and ATP. Samples $(30 \mathrm{ml})$ were removed from the incubation medium and centrifuged at $2000 \mathrm{~g}$ for $2 \mathrm{~min}$. The algae were disrupted by vortexing the cells for $2 \mathrm{~min}$ in $1 \mathrm{ml}$ of ice-cold $1 \mathrm{M}-\mathrm{HClO}_{4}$ with $1.5 \mathrm{~g}$ glass beads $(0.5 \mathrm{~mm}$ diameter). Insoluble material was removed from the extract by centrifugation for $4 \mathrm{~min}$ at $10000 \mathrm{~g}$. The supernatant was neutralized with $5 \mathrm{M}-\mathrm{K}_{2} \mathrm{CO}_{3}$, cooled for $1 \mathrm{~h}$ at $0{ }^{\circ} \mathrm{C}$ and centrifuged again. This final supernatant was used for the assay of glycerol and ATP.

Assay of glycerol and ATP. Glycerol in the supernatant was determined using an enzymic assay system with glycerokinase, pyruvate kinase and lactate dehydrogenase (Boehringer). The complete conversion of glycerol to lactate was followed by measuring the oxidation of NADH spectrophotometrically at $340 \mathrm{~nm}$. 
ATP was measured enzymically with hexokinase and glucose-6-phosphate dehydrogenase, by following the reduction of NADP+ at $340 \mathrm{~nm}$ (Bergmeyer, 1963).

All experiments were repeated at least twice with consistent results. Data from one self-contained experiment are presented in the figures.

\section{RESULTS}

\section{Effect of a weak acid and base on glycerol content}

To investigate whether changes in glycerol metabolism might be mediated by intracellular $\mathrm{pH}, D$. tertiolecta cells were incubated iso- or hyperosmotically in the presence of various concentrations of potassium acetate $(1,3,5,10$ or $20 \mathrm{mM})$ or ammonium chloride $(10,20$ or $50 \mathrm{mM})$ at different $\mathrm{pH}$ values.

Irrespective of the conditions, an iso-osmotic cell transfer did not affect the cellular glycerol content, which was 23 or $230 \mathrm{fmol}$ per cell for cells cultured at $0 \cdot 1$ or $0.5 \mathrm{M}-\mathrm{NaCl}$, respectively (data not shown). Glycerol accumulated at a rate of $200 \mathrm{fmol} \mathrm{per} \mathrm{cell} \mathrm{h}^{-1}$ after an hyperosmotic shock $(0 \cdot 1-0.6 \mathrm{M}-\mathrm{NaCl})$ at $\mathrm{pH}$ values between 4 and 7 in the absence of acetate. Yet, glycerol production was reduced to $130 \mathrm{fmol}$ per cell h-1 when the same experiment was done at $\mathrm{pH} 8$ or 9. With $3 \mathrm{~mm}$-acetate at $\mathrm{pH} 4$ or with $10 \mathrm{~mm}$-acetate at $\mathrm{pH} 5$, the hyperosmotic response was seriously disturbed (Fig. 1 a). At low pH values of the medium, acetate, which is mainly present in the uncharged protonated form ( $\mathrm{pK}^{\prime}$ of acetic acid is $4 \cdot 75$ ), could easily permeate across the plasmalemma and consequently decrease the intracellular $\mathrm{pH}$. Acetate treatment did not induce glycerol synthesis in the absence of an osmotic shock under any of the conditions tested (data not shown).

Alkaline buffers of $\mathrm{pH} 8$ and 9 slightly inhibited osmoinduced glycerol synthesis even in the absence of ammonium (Fig. 1 b). Inhibition of glycerol production by ammonium occurred at $\mathrm{pH} \mathrm{7,8}$ and 9, but was greatest at $\mathrm{pH} 9$. The $\mathrm{pK}^{\prime}$ of ammonium is $9 \cdot 25$, indicating that at high medium $\mathrm{pH}$ the intracellular $\mathrm{pH}$ will rise significantly by free permeation of $\mathrm{NH}_{4} \mathrm{OH}$. Here again neither ammonium nor $\mathrm{pH}$ had any effect on glycerol synthesis under control conditions.

\section{The effect of proton translocators}

The glycerol content in cells subjected to an hyperosmotic shock remained approximately at the same level when they were incubated in the presence of $1 \mathrm{mM}$-dinitrophenol (DNP) between
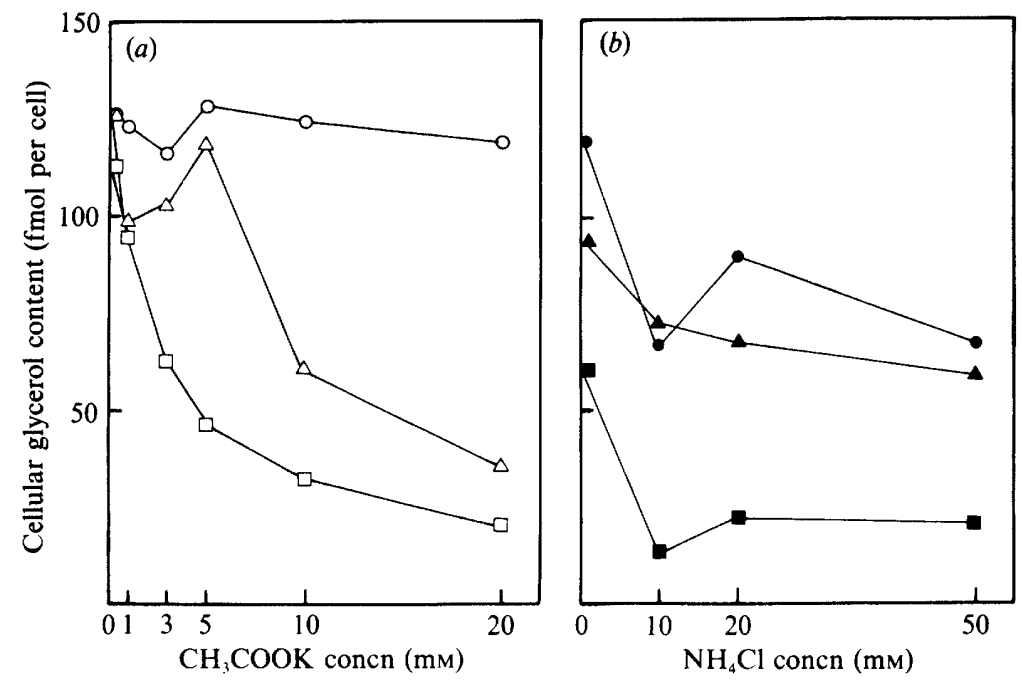

Fig. 1. Effect of acetate $(a)$ and ammonium ions $(b)$ on glycerol synthesis in D. tertiolecta cells subjected to hyperosmotic stress $(0 \cdot 1-0.6 \mathrm{M}-\mathrm{NaCl})$ at $\mathrm{pH} 4(\square), \mathrm{pH} 5(\triangle), \mathrm{pH} 6(\mathrm{O}), \mathrm{pH} 7(\mathcal{O}), \mathrm{pH} 8(\Delta)$ and pH 9 (ם). Each point represents the cellular glycerol content 30 min after the start of the upshock. The glycerol content of the cells before shock was $23 \mathrm{fmol}$ per cell. 


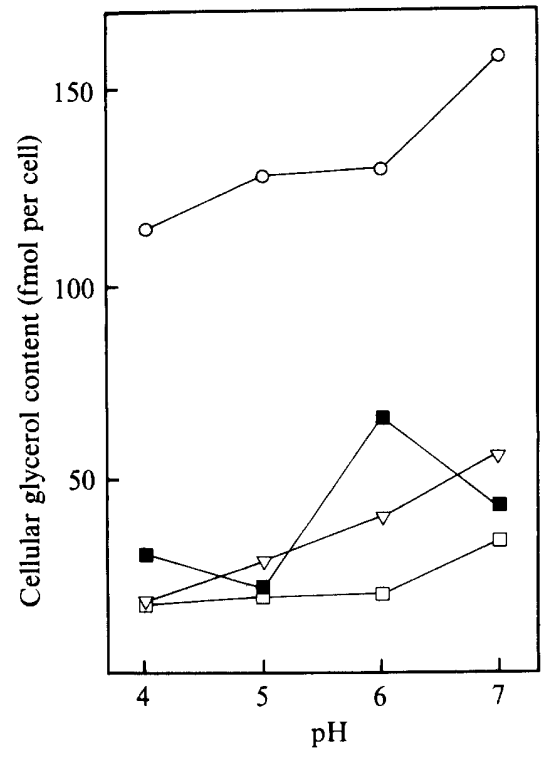

Fig. 2

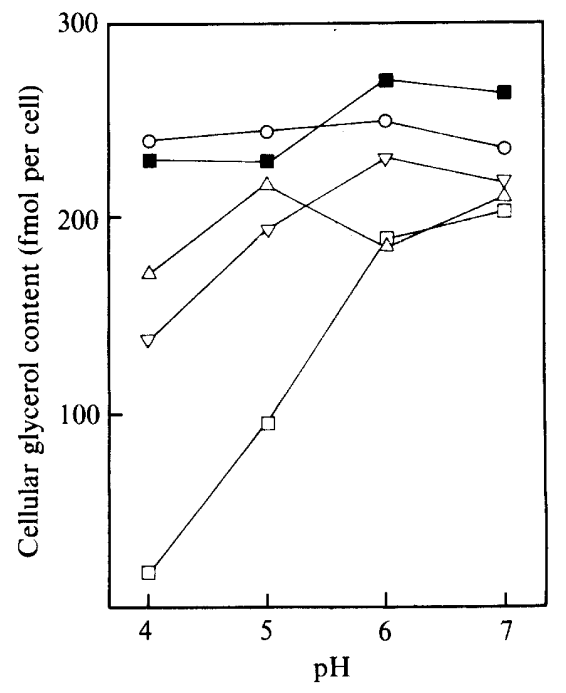

Fig. 3

Fig. 2. Effect of DNP and CCCP on the glycerol content of hyperosmotically stressed $(0 \cdot 1-0.6 \mathrm{M}-\mathrm{NaCl})$ D. tertiolecta cells at different transfer medium $\mathrm{pH}$ values. The glycerol content was measured $30 \mathrm{~min}$ after cell transfer. Cellular glycerol content before treatment of the cells was $23 \mathrm{fmol}$ per cell. $O$, Control; $\nabla, 0.3 \mathrm{~mm}-\mathrm{DNP}$; $\square, 1 \mathrm{mm-DNP}$; $\square, 0.05 \mathrm{~mm}-\mathrm{CCCP}$.

Fig. 3. Effect of DNP and CCCP on the glycerol content in $0.5 \mathrm{M}-\mathrm{NaCl}$-grown $D$. tertiolecta cells, after transfer to iso-osmotic media at various $\mathrm{pH}$ values. The glycerol content was measured $30 \mathrm{~min}$ after transfer to fresh medium. Glycerol content in the untreated cells was $230 \mathrm{fmol}$ per cell. $\bigcirc$, Control; $\triangle$, $0.1 \mathrm{~mm}-\mathrm{DNP} ; \nabla, 0.3 \mathrm{~mm}-\mathrm{DNP} ; \square, 1 \mathrm{~mm}-\mathrm{DNP} ; \mathbf{0}, 0.05 \mathrm{~mm}-\mathrm{CCCP}$.

pH 4 and 6 (Fig. 2); with 0.3 mM-DNP progressive but small increases were observed between pH 5 and 7. With cells grown in $0.5 \mathrm{M}-\mathrm{NaCl}$, some glycerol was lost to the medium in the presence of $0.3 \mathrm{~mm}$-DNP at $\mathrm{pH} 4$ and 5 and this loss was increased in the presence of $1 \mathrm{mM}$-DNP (Fig. 3). Under the latter conditions the cells died. Under the same conditions, the proton carrier carbonyl cyanide $m$-chlorophenylhydrazone (CCCP), at concentrations up to $0.05 \mathrm{M}$, did not affect the leaking of cellular glycerol in $0.5 \mathrm{M}-\mathrm{NaCl}$-grown cells even when tested at $\mathrm{pH} 4$ and 5 (Fig. 3). Nevertheless, when $0 \cdot 1 \mathrm{M}-\mathrm{NaCl}$-grown cells were hyperosmotically stressed in the presence of $\mathrm{CCCP}$, glycerol accumulation was significantly reduced, especially at the lower $\mathrm{pH}$ values; with 0.05 mM-CCCP no cellular glycerol production was observed at pH 4 and 5 (Fig. 2). Yet, under the same conditions but at $\mathrm{pH} 6$ and 7, glycerol still accumulated at a rate of about $50 \mathrm{fmol}$ per cell $\mathrm{h}^{-1}$.

The effect of these uncouplers is unlikely to be mediated only by changes in internal $\mathrm{pH}$, but probably also by their effect on intracellular ATP content. This was verified in the experiments described in Figs 4 and 5, which showed that DNP and CCCP did indeed drastically reduce ATP content. With DNP the ATP content under iso-osmotic conditions roughly correlated with glycerol retention by the cells and was only affected at $\mathrm{pH} 4$ (Fig. $4 a$ ). The additional stress of a hyperosmotic shock further reduced ATP content even at higher $\mathrm{pH}$ values of the medium (Fig. $5 a$ ). The effect of CCCP on the cellular ATP level was even more dramatic: ATP content was reduced to about $20 \%$ during hyperosmotic shock at all $\mathrm{pH}$ values tested (Fig. $5 \mathrm{~b}$ ). Under isoosmotic conditions the effect was most marked at pH 4 but was also significant $(50 \%)$ at the other $\mathrm{pH}$ values tested.

\section{Effect of some other ionophores}

After an hyperosmotic shock with mannitol, glycerol synthesis was not affected when $\mathrm{Na}^{+}$ was replaced with $\mathrm{K}^{+}$in the medium. Also the presence of valinomycin had no effect under these 

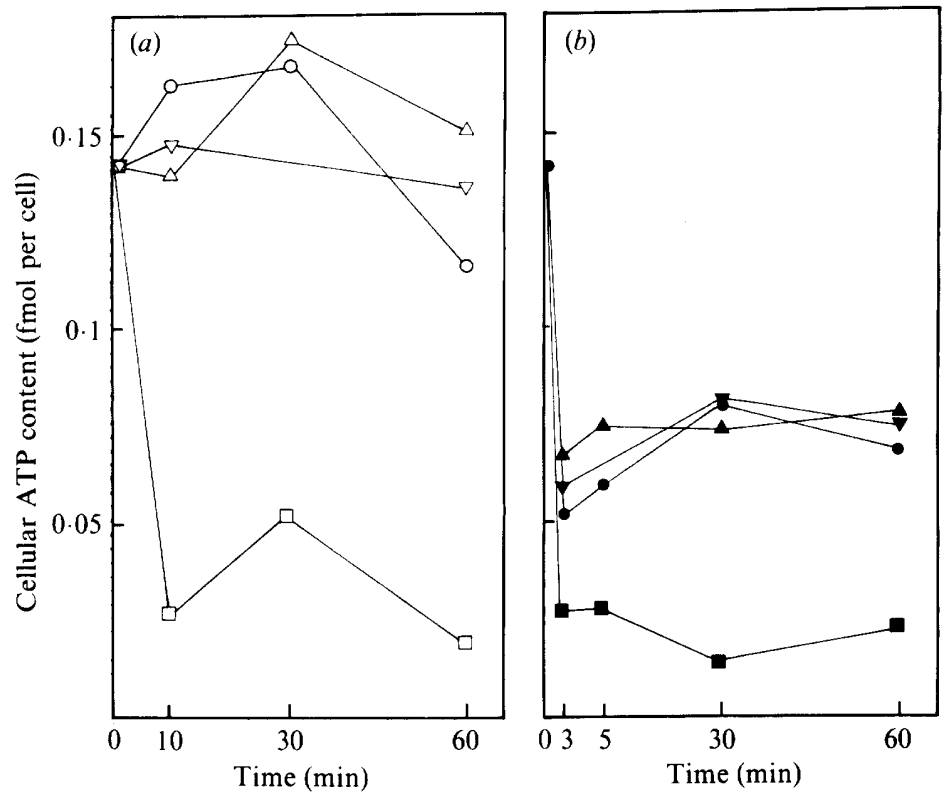

Fig. 4. ATP content in $0.5 \mathrm{M}-\mathrm{NaCl}$-grown $D$, tertiolecta cells at different time intervals after iso-osmotic cell transfer in the presence of $0.3 \mathrm{mM}$-DNP ( $a$, open symbols) or $0.01 \mathrm{mM}$-CCCP ( $b$, filled symbols). pH of transfer medium; $4(\square, \square) ; 5(\nabla, \nabla) ; 6(\triangle, \Delta) ; 7(O, \bigcirc)$.
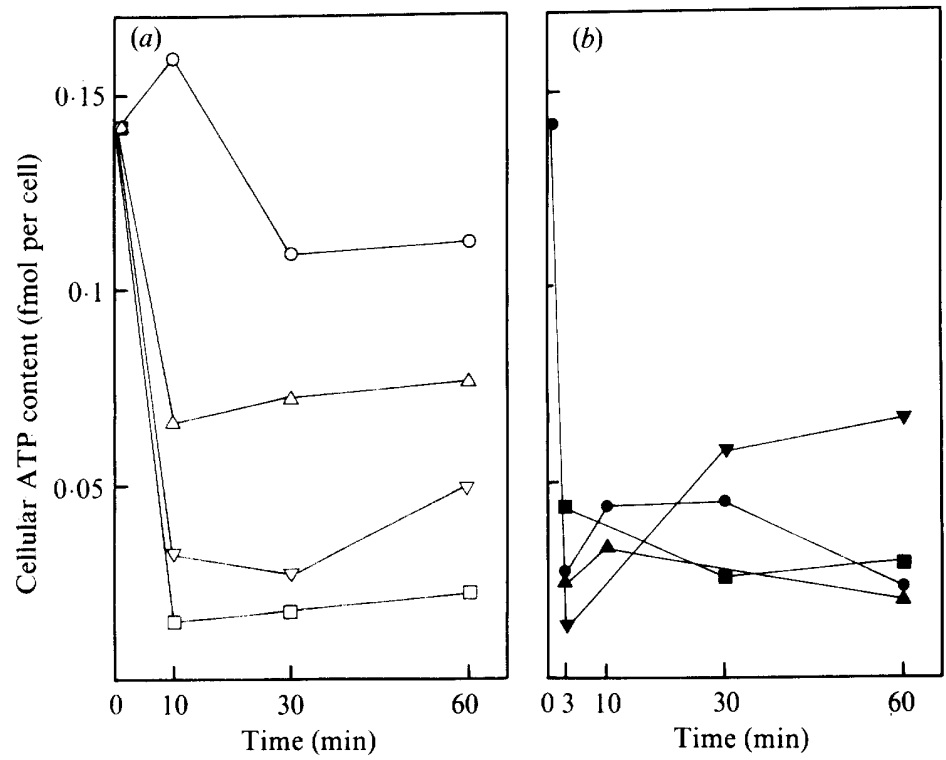

Fig. 5. ATP content in $0.1 \mathrm{M}-\mathrm{NaCl}$-grown $D$. tertiolecta cells, at different time intervals after an hyperosmotic cell transfer in the presence of either $0.3 \mathrm{mM}-\mathrm{DNP}$ ( $a$, open symbols) or $0.01 \mathrm{mM}-\mathrm{CCCP}$ (b, filled symbols). $\mathrm{pH}$ of transfer medium; $4(\square, \square) ; 5(\nabla, \nabla) ; 6(\triangle, \Delta) ; 7(\bigcirc, \bigcirc)$.

conditions. Nigericin in $0 \cdot 1 \mathrm{M}-\mathrm{K}^{+}$and monensin in $0 \cdot 1 \mathrm{M}-\mathrm{Na}^{+}$, however, almost completely abolished the stress-induced glycerol synthesis (Fig. 6a). The effects of the ionophores on glycerol synthesis paralleled their effects on the ATP content of the cells (Fig. 6b). Valinomycin caused a transient lowering of the ATP content, as seen for a control hyperosmotic shock. In the presence of monensin and nigericin, however, ATP content did not increase afterwards and 

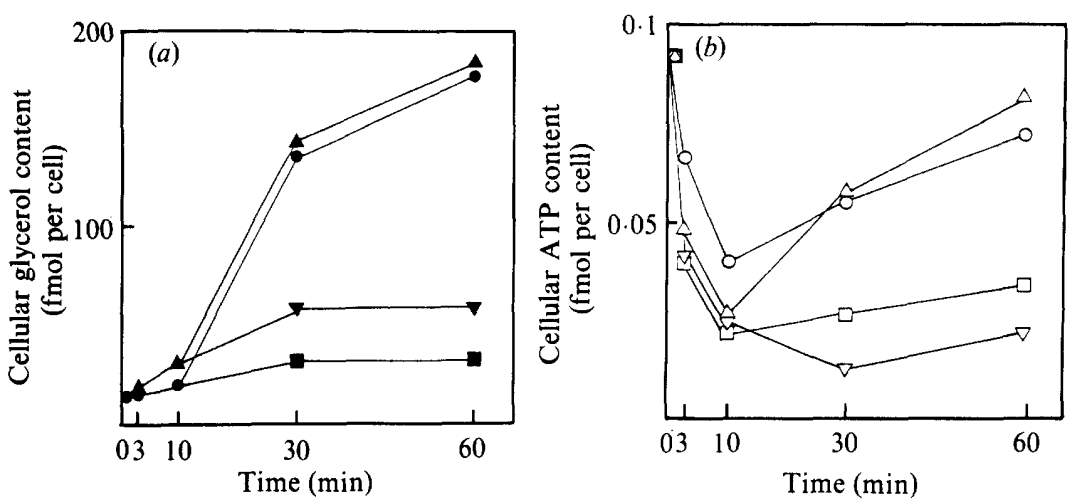

Fig. 6. Effect of various monovalent cation ionophores on the glycerol ( $a$, filled symbols) and ATP content ( $b$, open symbols) of $0 \cdot 1 \mathrm{M}-\mathrm{NaCl}$-grown $D$. tertiolecta cells. At time zero the cells were transferred to the following media: $(\mathrm{O}, \mathrm{O})$ culture medium with $0 \cdot 1 \mathrm{M}-\mathrm{KCl}+0.821 \mathrm{M}-\mathrm{mannitol} ;(\triangle$, $\Delta$ ) culture medium with $0.1 \mathrm{M}-\mathrm{KCl}+0.821 \mathrm{M}$-mannitol $+0.01 \mathrm{~mm}$-valinomycin; $(\nabla, \nabla)$ culture medium with $0.1 \mathrm{M}-\mathrm{KCl}+0.821 \mathrm{M}$-mannitol $+0.01 \mathrm{~mm}$-nigericin; $(\square, \square)$ culture medium with $0 \cdot 1 \mathrm{M}$ $\mathrm{NaCl}+0.821 \mathrm{M}$-mannitol $+10 \mu \mathrm{g}$ monensin $\mathrm{ml}^{-1}$.

remained at some $30 \%$ of the control levels. Under iso-osmotic conditions monensin and nigericin reduced the ATP content to nearly $50 \%$ whereas valinomycin had no detectable effect (data not shown).

\section{DISCUSSION}

Several authors (Ben-Amotz \& Avron, 1981; Gimmler et al., 1981) suggested that a fine control of the intracellular proton concentration might be involved in the regulation of glycerol metabolism in Dunaliella cells under different osmotic conditions. Indeed, since both glycerol dehydrogenase (Ben-Amotz \& Avron, 1974) and glycerol-3-phosphate dehydrogenase (Marengo et al., 1985) have different $\mathrm{pH}$ optima for their reduction and oxidation reaction sites, small changes in the internal $\mathrm{pH}$ might alter the rate of glycerol synthesis. Treatments with different concentrations of acetate or ammonium ions at different $\mathrm{pH}$ values were used to change the intracellular $\mathrm{pH}$. Depending on the $\mathrm{pH}$ of the medium and the concentration of the weak acid or base, different changes in intracellular $\mathrm{pH}$ are to be expected. Indeed the uncharged $\mathrm{CH}_{3} \mathrm{COOH}$ and $\mathrm{NH}_{4} \mathrm{OH}$ can be expected to diffuse through the plasma membrane rather freely (Kwon \& Grant, 1971). However, synthesis of glycerol could not be induced in the absence of osmotic stress under any of the conditions expected to acidify or alkalinize the cytoplasm to different degrees. Therefore it is unlikely that cytoplasmic $\mathrm{pH}$ plays a signalling role in glycerol metabolism. More dramatic changes in cellular $\mathrm{pH}$ both on the alkaline and acidic side in the presence of a weak acid or base greatly reduce the osmotic-stress-induced glycerol synthesis, probably by a general disturbance of cell metabolism.

Subsequently cellular pH was manipulated, perhaps more gently, by small concentrations of proton ionophores at different $\mathrm{pH}$ values. Proton ionophores (DNP and CCCP used here) make membranes permeable for protons and consequently destroy cellular proton gradients, thus possibly affecting cellular ATP content. Since the disturbance of glycerol metabolism by these agents, after hypertonic (Fig. 2) as well as isotonic (Fig. 3) cell transfer, was correlated with a permanent decrease in ATP content (Figs 4 and 5), the effect on glycerol metabolism is most probably caused by the uncoupling properties of these agents. Both photosynthetic and glycolytic production of glycerol are dependent on adequate cellular energy status. The effects of DNP are markedly $\mathrm{pH}$ dependent and remarkably more pronounced under osmotic stress conditions. The effect of CCCP on ATP content is less $\mathrm{pH}$ dependent (except at $\mathrm{pH} 4$ ) but is more pronounced than the DNP effect. Nevertheless it hardly affects glycerol retention but 
greatly inhibits glycerol synthesis. Together the data corroborate the importance of the energy status for glycerol synthesis but not for glycerol retention. The leaking of glycerol from DNPtreated cells cannot be due to its effect on ATP content alone since it does not occur with CCCP, which has an even more dramatic effect on ATP content.

A similar correlation between decreasing glycerol and ATP contents was obtained with the antibiotics nigericin and monensin (Fig. 6), again indicating the requirement of ATP for glycerol synthesis. These carboxylic ionophores can catalyse the overall electroneutral exchange of $\mathrm{K}^{+}$or $\mathrm{Na}^{+}$for protons (Pressman, 1976). In doing so they abolish $\mathrm{Na}^{+}, \mathrm{K}^{+}$and often proton gradients across the membrane. Valinomycin, on the other hand, a mobile carrier ionophore which catalyses the electrical uniport of $\mathrm{K}^{+}$, abolishes transmembrane electrical potentials but not proton gradients. Since valinomycin had no effect on cellular ATP content (Fig. 6b), ATP synthesis in $D$. tertiolecta seems to be driven mainly by proton gradients. Consequently glycerol synthesis was not affected (Fig. $6 a$ ) by this ionophore.

Concluding, it was impossible to alter glycerol synthesis by procedures to affect cellular $\mathrm{pH}$ or ion content. All treatments affecting glycerol synthesis probably did so by diminishing cellular ATP content. It is therefore unlikely that changes in $\mathrm{pH}$ or ion content would trigger the start of glycerol synthesis after an hyperosmotic shock. Also membrane potential does not seem to play an important role. Although a temporary lowering of ATP content might be important for triggering glycerol synthesis, adequate cellular ATP pools are necessary for lasting glycerol accumulation.

\section{REFERENCES}

Belmans, D. \& VAN LAERE, A. (1987). Glycerol cycle enzymes and intermediates in Dunaliella tertiolecta cells during hyperosmotic stress. Plant, Cell and Environment 10, 185-190.

Ben-AMOTZ, A. \& Avron, M. (1973). The role of glycerol in osmotic regulation of the halophilic alga Dunaliella parva. Plant Physiology 51, 875-878.

BEN-AMOTZ, A. \& Avron, M. (1974). Isolation, characterization and partial purification of a reduced nicotinamide adenine dinucleotide phosphate-dependent dihydroxyacetone reductase from the halophilic alga Dunaliella parva. Plant Physiology 53, 628-631.

BEN-AMOTZ, A. \& AvRon, M. (1981). Glycerol and $\beta$ carotene metabolism in the halotolerant alga Dunaliella: a model system for biosolar energy conversion. Trends in Biochemical Sciences 6, 297-299.

Bergmeyer, H. U. (1963). Methods of Enzymatic Analysis. New York: Academic Press.

Borowitzka, L. J., Kessly, D. S. \& Brown, A. D. (1977). The salt relations of Dunaliella. Further observations on glycerol production and its regulation. Archives of Microbiology 113, 131-138.

Brown, A. D., Lilley, R. McC. \& Marengo, T. (1982). Osmoregulation in Dunaliella. Intracellular distribution of enzymes of glycerol metabolism. Zeitschrift für Naturforschung 37C, 1115-1123.

BusA, W. B. \& Nuticelli, R. (1984). Metabolic regulation via intracellular $\mathrm{pH}$. American Journal of Physiology 246, R409-R438.

EHRENFELD, J. \& COUSIN, J.-L. (1982). Ionic regulation of the unicellular green alga Dunaliella tertiolecta. Journal of Membrane Biology 70, 47-57.

EhrENFELD, J. \& CoUSIN, J.-L. (1984). Ionic regulation of the unicellular green alga Dunaliella tertiolecta: response to hypertonic shock. Journal of Membrane Biology 77, 45-55.
GiNZBURG, M. (1981). Measurement of ion concentrations in Dunaliella parva subjected to hypertonic shock. Journal of Experimental Botany 32, 333-340.

Gimmler, H., Wiedemann, C. \& Moller, E. M. (1981). The metabolic response of the halotolerant green alga Dunaliella parva to hypertonic shocks. Berichte der Deutschen botanischen Gesellschaft 94S, 613-634.

Haus, M. \& WegmanN, K. (1984a). Glycerol-3phosphate dehydrogenase (EC 1.1.1.8) from Dunaliella tertiolecta. I. Purification and kinetic properties. Physiologia plantarum 60, 283-288.

HaUs, M. \& WegmanN, K. (1984b). Glycerol-3phosphate dehydrogenase (EC 1.1.1.8) from Dunaliella tertiolecta. II. Influence of phosphate esters and different salts on the enzymatic activity with respect to osmoregulation. Physiologia plantarum 60, 289293.

KatZ, A., KabaCK, H. R. \& Avron, M. (1986). $\mathrm{Na}^{+} / \mathrm{H}^{+}$antiport in isolated plasma membrane vesicles from the halotolerant alga Dunaliella salina. FEBS Letters 202, 141-144.

Kwon, Y. M. \& Grant, B. R. (1971). Assimilation and metabolism of glucose by Dunaliella tertiolecta. I. Uptake by whole cells and metabolism by cell free systems. Plant and Cell Physiology 12, 2939.

Lerner, H. R., Sussman, I. \& AVRon, M. (1980). Characterization and partial purification of dihydroxyacetone kinase in Dunaliella salina. Biochimica et biophysica acta 615, 1-9.

Marengo, T., Lilley, R. McC. \& Brown, A. D. (1985). Osmoregulation in Dunaliella. Catalysis of the glycerol-3-phosphate dehydrogenase reaction in a chloroplast enriched fraction of Dunaliella tertiolecta. Archives of Microbiology 142, 262268. 
Pick, U., KaRni, L. \& Avron, M. (1986). Determination of ion content and ion fluxes in the halotolerant alga Dunaliella salina. Plant Physiology 81, 92-96.

Pressman, B. C. (1976). Biological applications of ionophores. Annual Review of Biochemistry 45, 501530.

Smith, F. A. \& RAVEN, J. A. (1979). Intracellular pH and its regulation. Annual Review of Plant Physiology 30, 289-311.
Sussman, I. \& Avron, M. (1981). Characterization and partial purification of DL-glycerol-1-phosphatase from Dunaliella salina. Biochimica et biophysica acta 661, 199-204.

WEgmanN, K. (1979). Biochemical adaptation of Dunaliella tertiolecta to salinity and temperature changes. Berichte der Deutschen botanischen Gesellschaft 92, 43-54. 